\title{
Passive Double Skin Façade (DSF) Basic Components and Functions
}

\author{
M. H. M. Zin, M. Jamil, N. L. N. Ibrahim, A. S. M. Tazilan
}

\begin{abstract}
Efficient building design is not impossible to be achieved in construction industry. Due to the various environmental issues that related to the building design, architects and people in the construction industry try to create an environmental friendly building design. Function as the main transition building element, building facade plays a major role to control and prevent the unnecessary elements from outside to enter the interior building space. Double Skin Facade (DSF) possessed a high potential to provide multifunction benefits to the building design, human and environment. There are various definitions that being applied to defined each of the DSF design and functions. This paper reveals some of the definitions and functions that related to the basic components for DSF such as cavity, inner and outer skin glaze facade and shading device. Each of the DSF's components has its own functions to provide a better building design. Information regarding on each of the DSF's components are highlighted that base on the literature review. All of the information is tabulates to identify the percentage of each basic component for DSF. This research reveals the definitions and functions regarding on the basic component for passive DSF as a source to increase the understanding and knowledge especially for those who are involved in the construction industry.

Keywords : Passive, Double Skin Facade, Basic Component, Functions.
\end{abstract}

\section{INTRODUCTION}

\section{B} design that gives the first impression from the outside view. As the external physical appearance, building's facade determines the age, architectural style, technology and era when it was built. It is essential to design an efficient facade system to suit with the changes of the environment as well as providing better occupant needs [48]. Normally, building's facade or also known as building's envelope function to

Revised Manuscript Received on February 05, 2020.

* Correspondence Author

M. H. M. Zin*, Architecture Department, Faculty of Engineering and Built Environment, 43600 National University of Malaysia, Malaysia (phone: 012-9446404; e-mail: bay_sir_nar86@yahoo.com).

M. Jamil, Architecture Department, Faculty of Engineering and Built Environment, 43600 National University of Malaysia, Malaysia (e-mail: maslinajamil@ukm.edu.my).

N. L. N. Ibrahim, Architecture Department, Faculty of Engineering and Built Environment, 43600 National University of Malaysia, Malaysia (e-mail: nlni@yahoo.com)

A. S. M. Tazilan, Architecture Department, Faculty of Engineering and Built Environment, 43600 National University of Malaysia, Malaysia (e-mail: azimintazilan@ukm.edu.my).

(C) The Authors. Published by Blue Eyes Intelligence Engineering and Sciences Publication (BEIESP). This is an open access article under the CC BY-NC-ND license (http://creativecommons.org/licenses/by-nc-nd/4.0/) protect the interior building's space. In the other hands, building's facade plays a vital role to allow or prevent the necessary even the unnecessary natural environment that potentially creates negative impact to the building design. Due to the current issue associated with high energy consumption and carbon dioxide emission has been a major factor to improve the building facade as the most effective interventions [43]. According to Aksamija [2], facades play a major role that function as a barrier between indoor and outdoor spaces. Besides, facade also functions as the vital role especially to create an efficient building design via the strategy of energy management for a building design [43].

In modern architecture, glass facade widely being used particularly on commercial buildings for aesthetics, lightweight and daylight purposes [16]. Besides, Gratia \& Herde [43] believed that building glass facade also lies with multiple functions which not only focus on the day light penetration to a building. Different geography and climate create different impact to the function of building's facade design. A building facade located in cool climate definitely creates a different function compare to the building located in the tropical climate. Designers need to understand the connection between a building's facade design with the exterior and interior space. An efficient building design should be equipped with an efficient building's facade design. Double skin facade design (DSF) possesses high potential to be part of the building's elements that contribute to create an efficient building design.

The earliest double skin facade (DSF) was constructed during 1903 in Germany [46]. In the last decade, designers prefer to adopt the DSF integrated with the glazed office building has increased [15]. Currently, DSF is not a new type of architectural building's element. DSF is getting more attention due to its ability especially on the decreased of energy consumption Mulyadi et al. [34], energy conservation and creates good door environment [12]. As a multifunctional facade, DSF gives positive impact to a building design and accommodating a comfortable space to stay. It is in line with research done by Baharvand et al. [4] revealed that DSF provides various advantages and also creates negative impacts due to the inappropriate study. The application of DSF potentially enhances the building energy performance that improves the user control and comfort [44] [48]. Due to the multiple positive impacts on the building design, various researches has been undertaken and reported including study on daylight. Majority of current research is focusing on the ventilation, thermal performance and solar radiation [32]. Study on the effect of daylight to DSF and building performance will give extra benefits. Ghonimi [17] revealed that,

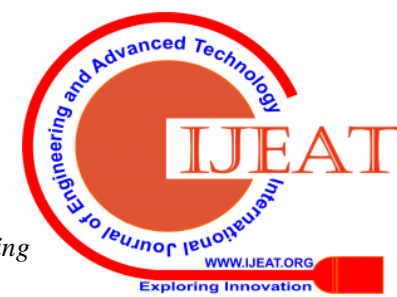


DSF meet the lighting problems that can solve the issue on the insufficient and extra glare of daylight. Moreover, according to the research, DSF function in controlling the daylight penetration and heat gain to provide an effective ambience of the indoor space quality.

Passive design strategy operates without assisted by any complicated mechanical and electrical system while active design strategy needs to operate with mechanical and electrical system. Passive design strategy produces less energy consumption compared with active design strategy and need to control especially on operation cost. This is in line with research done by Barbosa \& Ip [5] proved that a passive system applied to a building has risen to solve issue in the building construction industry especially on the energy impact. Various elements for the passive system can be implementing in an office building design [36]. Abdul Aziz \& Mohd Adanan [1] stated that active design architecture features are elements that respond to the environment actively while passive design elements are attached permanently to the building design and passively respond to the environment. Architects are responsible to focus on the passive building technology especially design to reduce energy building's consumption [24]. Insulation, day lighting, opening windows and building's shading elements are considered as among the natural design strategy for building design [52]. DSF operated in a passive and active system that depends on the needs of the occupant in a building's space and the interaction between the building designs with the climate condition. This research focuses on the passive DSF design that contributes to producing a quality daylight performance in a building due to the efficient of energy consumption and providing a sustainable architectural building system.

\section{RESEARCH METHODOLOGY}

This research used literature review as the main source to study the basic components for DSF. All of the information is tabulates to identify the percentage of each basic component for DSF. The highest percentage indicates as the major basic components that contribute in the DSF functions as well as the most factor being discussed and study.

Currently, various definitions are being used that depend on the function of the facade, climate and building's program. A DSF possessed of three main elements which are the original facade, cavity and an additional external glass skin [5]. DSF function as a system that contains two glass layers were provided with natural or mechanical airflow within the cavity space [41]. DSF is an arrangement series of glass layers that located in front of the original facade [13]. Xue \& $\mathrm{Li}$ [54] stated that, DSF is one of the building façade that consist of double skin glasses with a cavity which sometimes provided with shading elements and air vents. DSF is a building façade that equipped with a separated cavity air gap with various depths and located within two layers of façade [44]. DSF is a covering facade for more than one story building with multiple building airtight skins and integrates with active and passive ventilation system [11]. As a multiple building façade design, DSF is provided with a buffer space located within external and internal glass skin

\section{DEFINITIONS AND FUNCTIONS}

[9] [54] [46] that act as solar harvesting and ventilation controller purposes [37]. Separated by a cavity space that provided with shading device and ventilation purposes [34], DSF has two layers of different glass type that located at the interior and exterior of a building design [35]. Ding et al. [12] stated that, normally DSF contains of internal and external skin façade with a space located between both facades. As an efficient building envelope, DSF is provided with a second layer of transparent glass façade that located near to the original building façade [47]. Joe et al. [24] described DSF as one of the passive building façade system that consists of cavity that provides various functions located between two of glass façade's.

According to Poirazis [41] numerous and different DSF's name are being used that base on its specific issue, objective and function. DSF can be defined in a more specific name that depends on the system, mechanism and its function. A research done by Larsen et al. [28] used the term of double skin glazed facade (DGF) that consist of a cavity gap that located between two layers of façade which are the external façade and original building façade as the main DSF's components. Besides, Andelkovic et al. [3] classified DSF into a more detail terminology called as naturally ventilated double skin facades (NVDSF) that possessed the similar components with DSF but more focus on the ventilation system. Loncour et al. (2004) defined DSF as a ventilated double-facade (VDF) or called as the climatic facade that equipped with a cavity space as a separator between two layers of glass building facade that can be placed with shading device. VDF design purposes are more focus on the ventilation effects and mode to the building compromise with two types of facades which are passive VDF and active VDF. VDF is quite related with NVDSF where it possessed of a gap known as a cavity space that function as separator for two layers of glass skin facade and can be placed by solar control or shading device [32]. Peng et al. [40] done a research on DSF called as a ventilated building-integrated photovoltaic (BIPV) facades that concentrated on the airflow within the cavity area that integrated with photovoltaic (PV) glazing Luo et al. [33] defined DSF as multilayer glazing glass (MGF) that focus on the performance of solar transmission through multilayer glass by using shading devices,

DSF create various benefits to the office building design. Pollard \& Beatty [42] revealed that DSF has high ability to minimize energy consumption, reduce the negative impact from the external condition or environment and permit day lighting to the indoor space of a building. The authors also revealed that DSF potential to reduce energy use by reducing heat demand, control solar gain, allow natural ventilation, acoustic protection, views, enhanced security, emergency egress, pollution barrier and increased access to daylight such as reduced artificial lighting. Besides, Hendriksen et al. [21] stated that DSF provides variety of benefits to the building such as transparency, day lighting/ outside view, acoustic, shading device, cooling at night, natural ventilation and heat loss.

Goia et al. [18] criticized where current research mostly focuses on the thermal aspects and potential saving on energy consumption while most study should be focus on the effect that produced by the environment and day lighting purposes. 
Various definitions and functions are related to DSF design base on the previous study. It shows that DSF as the multifunctional building facade creates variety of benefits to the building design. DSF functions base on the issue and objective that contributes to provide an efficient building design for the occupant.

\section{DSF COMPONENTS}

Various researches and studies have been done that propose the various DSF components respond to the building needs and site characteristics. Research done by Barbosa and Ip [5] stated that cavity depth, shading device, cavity space, structure and external glass façade considered as part of the main elements for the DSF components. Technically, DSF encompasses of three main elements which are ventilated cavity gap as the intermediate space, outer and inner skin glass layer [12]. According to Lee et al. [30], DSF consists of cavity space, adjustable shading devices and curtain wall glazing system. DSF is known as a building's façade that equipped with an air cavity gap located between two layers of glass, shading devices and openings [26]. This paper will discusses the basic elements for DSF which are cavity, inner and outer skin glass facade and shading device as the main components for passive DSF that provide a quality of day lighting performance inside the building.

\section{A. Cavity}

A cavity is a space located between two layers of glasses known as inner and outer glass facade. Cavity creates a special character that plays a major role in DSF that make it different than the other architectural elements. Joe et al. [24] stated that, the cavity is the main components that determine the passive DSF design strategy for natural ventilation, solar radiation control and insulation. Besides, this research revealed that the cavity depth will determine the energy consumption in a building. A proper design of cavity space potentially provides with various benefits especially for building energy purposes [5]. The cavity also acts as a protector from the unnecessary microclimate effects to the building design [16]. According to Boake [19], cavity functions as an insulator to extreme temperature, air and sound. However, cavity also can create a negative impact in term of temperature and energy consumption due to the poor design consideration [45].

The depth of cavity plays a vital role to determine the impact on the building design. Various depths have been adapted to the DSF design depend on the building needs, site condition and climate. Pomponi et al. [43] stated that, a narrow cavity performed a better performance compared to a wide cavity. Ghaffarianhoseini et al. [16] stated that in order to determine the cavity depth, it should be based on the consideration of existing climatic impacts to the building design with specific cavity depth. Suggestion by Belgium Building Research Institute [8] showed that the efective cavity depth is in the range within $20 \mathrm{~cm}$ to $200 \mathrm{~cm}$. Research done by Pollard \& Beatty [42] they studied various building design that implements DSF in North America with $900 \mathrm{~mm}$ depth as the maximum cavity depth. The cavity depth is between $1 \mathrm{~m}$ to $2 \mathrm{~m}$ that depend on the different design concept [39]. The range from $200 \mathrm{~mm}$ to more than $2 \mathrm{~m}$ is the width of cavity between the two skin facades [10]. Boake et al. [9] studied three types of DSF with various cavity depths ranging from $150 \mathrm{~mm}$ to $900 \mathrm{~mm}$. A simulation study by Viljoen et al. [50] used the distance of $1.4 \mathrm{~m}$ for the cavity depth that located between original and outer glass façade. The authors defined this gap as an air duct for ventilation purposes as well as function for service walkway. Kurniansyah et al. [27] applied the various distances for the cavity gap consist of $30 \mathrm{~cm}, 60 \mathrm{~cm}, 90 \mathrm{~cm}$ and $120 \mathrm{~cm}$. Gavan et al. [14] revealed that a cavity space should be designed in various methods especially on its depth distance between both glass layers and produce positive impact of air volume.

As mentioned before, some of the DSF focus on certain mechanism using the different terminology. For VDF, a gap between two layers of glass is defined as a ventilated cavity that having a width between several centimeters to several meters [31]. In line with a research done by Jiru \& Haghighat [23], a cavity space can be function to protect the building interior space from the unnecessary heat, heat loss and thermal discomfort. Besides, the DSF's cavity gap plays a major role especially to reduce the thermal energy for a building space [12]. The cavity gap also plays a major role to control the heat losses depending on the air volume [38].

A research done by Ding et al. [12] showed that cavity plays a major role especially on the natural ventilation that assisted by solar chimney located on the DSF to create a stable performance. This research also revealed the relation between solar radiation and the stack effect of natural ventilation to provide a comfortable indoor space. Barbosa et al. [6] studied the role of cavity in term of relation between the thermal performance and the impact of natural ventilation within the occupied space. Good ventilation assists to provide an efficient thermal condition for the occupant and to create an efficient indoor quality space.

\section{B. Inner and outer skin glaze facade}

Currently, glaze facade becomes highly demand especially for an office building design. It gives various advantages and disadvantages to the building energy consumption. DSF consists of inner and outer skin glaze facade. Both of the glaze facade function together with cavity space and shading device to produce a comfortable indoor space area. Inner or known as original skin glass/ normal facade possesses its own function that integrated with outer skin glass facade as well as the cavity. For a Ventilation Double Facade (VDF), thermally-insulating double glazing is generally placed on the outside while the indoor glazing is generally reinforced single glazing that can be closed for most of the time or can be opened for maintenance purposes [31].

A research done by Goia et al. [18] revealed that, original façade which consider the percentage of window's to the building's wall create a small impact to the building's energy performance. Original building's facade also functions as an insulator [19] with an efficient design strategy. Selection of window's glass plays a major role on the energy need for cooling [51] as well as other various functions such as day lighting penetration, acoustic, thermal and etc.

The efficiency of window' design for DSF potentially can be enhances by selecting an appropriate of glass thickness for the original glass layer that reduce the energy consumption for cooling load [34].

According to Ding et al. [12], the external curtain glass building façade acts as a barrier against the climate issues, enhance the indoor building acoustic and as a protector from the unnecessary noise.

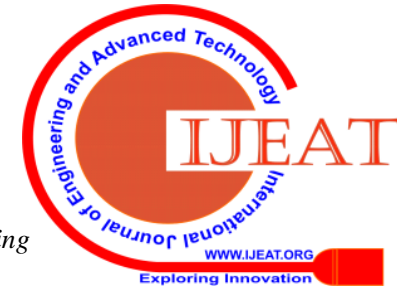


The outer skin commonly equipped with a strong full glass features as a protection from the external environmental impacts [10]. A simulation study done by Gratia \& Herde [20] applied a clear single glass for the external layer of DSF in a different type of a multi-story building's orientation. Thus, this study yields a positive impact to the building energy performance especially on the heating demand. A study done by Ignjatovic et al. [22] revealed that outer skin facade decreases in delivered heating energy but it will increases the cooling energy simultaneously if without a proper selection of glass. A suitable outer glass type will increases the indoor acoustic performance as a preventer from the negative external sounds especially traffic noise [7].

\section{Shading devices}

Shading device is another component for DSF that operate with cavity gap, inner and outer skin glass. Gratia \& Herde [19] stated that a cavity space function as the sun protection devices. It is important to consider the existence of shading device since it influences the depth of cavity space [31]. A research done by Viljoen et al. [50] showed that the appearance of shading device give the impact to the walkway (cavity gap) which it needs to be increase from $1.4 \mathrm{~m}$ to $1.9 \mathrm{~m}$. Three main considerations influence the effectiveness of shading device which are the site surrounding, design objective and climate characteristics. To adapt shading devices for DSF required a deep understanding on the main issue and purposes in the initial process of the design work. The integration between shading devices with cavity space and two layers of facade potentially produce a better building design performance. Lee et al. [29] revealed that shading devices are consist of two main types which are horizontal and vertical shading device that normally been equipped for DSF.

Shading device is an essentials building component to minimizing energy consumption for building services [53]. Shading devices has high potential that creates a significant impact to the building energy consumption [6]. Various type of shading devices can be implements to DSF that create numerous advantages to the building design. A study conducted by Lee et al. [30] showed that horizontal shading devices are more efficient compared to the vertical shading device especially on the reducing the building energy consumption. Goia et al. [18] stated that, it is suggested to implement the dynamic shading device due to its effective performance to harvest day light. Proper angles of shading devices influence the performance of solar transmission in a building design [33].Normally, shading devices is located within the cavity space to cater the over day lighting and glare issue. Shading device provides a better and uniform day lighting performance to the indoor office area especially to the space located far from the inner or original facade. Quality of daylight should be compromises while implementing the smart shading devices [38]. According to Winther et al. [53], the application of shading device will optimizes the transmittance of daylight and reduces on the demand of artificial light as well as avoiding glare.

Shading device also function as an insulator to reduce the energy consumption for cooling system in the building interior space [12]. Besides, Luo et al. [33] agreed that shading device potentially function to harvest the excessive solar heat and necessary to do a deep study to implement. Barbosa et al. [6] revealed that shading device is the major factor to reduce building thermal performance to produce an

efficient cavity space. Yang et al. [55] stated that shading devices potentially to prevent the absorption of excessive heat and improve the performance of interior thermal via effective window's design. Lee \& Chang [30] revealed that vertical shading device functions effectively for various purposes such as acoustical preventer, noise insulation, thermal barriers and ventilation. Besides, external shading device also successfully reduce the demand on lighting and decrease the thermal load.

[25]. The author also insists that appropriate control strategies on DSF and exterior shading device can significantly reduce the thermal loads with an effective percentage of energy performance. Implementing a proper openness for venetian blinds that function with the air flow within the cavity gap potentially improves the thermal performance [49]. Deep understanding on the site surrounding and building's functions assist designers to provide an effective DSF with a suitable shading device design. By using an appropriate angle of shading devices and airflow strategy, it will increase the efficiency on the heat transfer in DSF [26]. Shading device also possess a high potential to reduce temperature inside a building which in line with a research done by Papadaki et al. [38] showed that shading system (shading device) reduces the temperature effectively compared to the internal shading system.

\section{RESULTS AND DISCUSSIONS}

Three main basic components play a vital role to produce an efficient DSF that base on the certain factors especially on the site issues, design objectives and climates. Various studies have been done to enhance the quality of DSF and create benefit to the building, occupants and environment. Moreover, researchers identified and produced variety of idea or solution to improve the quality of DSF.

Table- I: Numbers of components that define DSF

\begin{tabular}{|c|c|c|c|c|c|c|c|c|c|}
\hline \multirow[b]{2}{*}{ No } & \multirow[b]{2}{*}{ Researchers } & \multirow[b]{2}{*}{ Year } & \multicolumn{7}{|c|}{ DSF's components } \\
\hline & & & 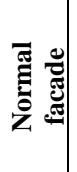 & : & 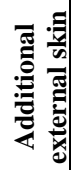 & 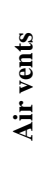 & क & 总曷 & 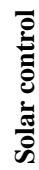 \\
\hline 1 & Oesterle & 2001 & 0 & & & & & & \\
\hline 2 & Saelans & 2002 & O & & & & & & \\
\hline 3 & Boake & 2003 & C & & & & & & \\
\hline 4 & Poirazis & 2004 & & & & & & & \\
\hline 5 & Loncour & 2004 & & O & & & 0 & & \\
\hline 6 & Safer & 2005 & & & & & & & \\
\hline 7 & Ding & 2005 & & & ? & & & & \\
\hline 8 & Chan & 2009 & & & & & & 0 & \\
\hline 9 & Rahmani & 2012 & & & 0 & & & & \\
\hline 10 & Mulyadi & 2012 & & O & O & O & 0 & & \\
\hline 11 & Lou et al. & 2012 & & O & O & & 0 & & O \\
\hline 12 & $\begin{array}{l}\text { Eren and } \\
\text { Erturan }\end{array}$ & 2013 & & & & & & & \\
\hline 13 & Peng & 2013 & & & 0 & & & & \\
\hline 14 & Joe & 2014 & 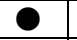 & 0 & ? & & & & \\
\hline 15 & $\begin{array}{l}\text { Barbosa and } \\
\text { Ip }\end{array}$ & 2014 & & & & & & & \\
\hline 16 & Xue and Li & 2015 & 0 & O & 0 & O & 0 & & \\
\hline 17 & $\begin{array}{l}\text { Nasrollahi } \\
\text { and Salehi }\end{array}$ & 2015 & & & & & & & \\
\hline 18 & Larsen e al. & 2015 & O & O & O & & & & \\
\hline
\end{tabular}




\begin{tabular}{|l|l|l|l|l|l|l|l|l|l|}
\hline 19 & Andelkovic & 2015 & 0 & $\mathbf{0}$ & $\mathbf{0}$ & & & & \\
\hline 20 & Luo & 2017 & 0 & & 0 & & $\bullet$ & & \\
\hline \multicolumn{3}{|c|}{ TOTAL } & 20 & 13 & 19 & 2 & 5 & 1 & 1 \\
\hline
\end{tabular}

Various researchers identify the best definition that base on certain components for DSF. Besides, some of the researchers define DSF base on their scope of study that relates with specific issue and objective. Moreover, some of them define DSF to a more detail definitions and specific on certain environmental elements such as ventilation, noise and heat.

Table-I indicates that normal façade is the compulsory components to define DSF by all of the researchers. The second component is additional external skin while cavity is the third highest component to define DSF. Four researchers include shading device as another component to strengthen the definition for DSF. Three basic components which are air cavity, shading device and normal façade with additional external skin are the major or known as basic components that been define by most of the researchers involve in DSF design. Five other researchers provide another additional component to define DSF such as air vents, multiple skins and solar control. These additional components enhance more on the efficiency of DSF to provide a better indoor environment for a building space.

Table-II: Numbers of study on the DSF basic components

\begin{tabular}{|c|c|c|c|c|c|}
\hline \multirow[b]{2}{*}{ No } & \multirow[b]{2}{*}{ Researchers } & \multirow[b]{2}{*}{ Year } & \multicolumn{3}{|c|}{ DSF's basic components } \\
\hline & & & Cavity & $\begin{array}{l}\text { Inner } \\
\text { and } \\
\text { outer } \\
\text { skin } \\
\text { glaze } \\
\text { facade }\end{array}$ & $\begin{array}{l}\text { Shading } \\
\text { device }\end{array}$ \\
\hline 1 & Viljoen et al. & 1997 & - & & 0 \\
\hline 2 & $\begin{array}{l}\text { Belgium Building } \\
\text { Research Institute }\end{array}$ & 2002 & O & & \\
\hline 3 & Boake & 2003 & & 0 & \\
\hline 4 & Loncour et al. & 2004 & - & 0 & ○ \\
\hline 5 & Poirazis & 2004 & - & 0 & 0 \\
\hline 6 & Ding et al. & 2005 & - & 0 & 0 \\
\hline 7 & Gratia and Herde & 2007 & & 0 & 0 \\
\hline 8 & Pollard and Beatty & 2008 & - & & \\
\hline 9 & Jiru and Haghighat & 2008 & - & & \\
\hline 10 & Pappas and Zhai & 2008 & - & & \\
\hline 11 & Gavan & 2010 & - & & \\
\hline 12 & Rundle & 2011 & - & & \\
\hline 13 & Kuznik & 2011 & & & - \\
\hline 14 & Papadaki et al. & 2012 & - & & 0 \\
\hline 15 & Ignjatovic & 2012 & & - & \\
\hline 16 & Mulyadi et al. & 2012 & & 0 & \\
\hline 17 & Chan & 2012 & & 0 & \\
\hline 18 & Goia & 2013 & & 0 & 0 \\
\hline 19 & Batungbakal & 2013 & & - & \\
\hline 20 & Joe & 2014 & - & & \\
\hline 21 & Barbosa and Ip & 2014 & - & & \\
\hline 22 & Chan et al. & 2014 & - & & \\
\hline 23 & Pomponi & 2015 & 0 & & \\
\hline 24 & Barbosa & 2015 & 0 & & - \\
\hline 25 & Lee & 2015 & & & - \\
\hline 26 & Silva & 2015 & & & 0 \\
\hline 27 & Lee and Chang & 2015 & & & 0 \\
\hline 28 & $\begin{array}{l}\text { Ghaffarianhoseini } \\
\text { et al. }\end{array}$ & 2016 & ○ & & \\
\hline 29 & Boake & 2016 & - & & \\
\hline 30 & Kurniansyah & 2016 & - & & \\
\hline 31 & $\begin{array}{l}\text { Wetsphal and } \\
\text { Andreis }\end{array}$ & 2016 & & 0 & \\
\hline 32 & Yang & 2016 & & & 0 \\
\hline 33 & Winther & 2017 & & & 0 \\
\hline
\end{tabular}

\begin{tabular}{|c|l|c|c|c|c|}
\hline 34 & Luo & 2017 & & & 0 \\
\hline 35 & Kim & 2018 & & & 0 \\
\hline \multicolumn{2}{|c|}{ TOTAL } & 19 & 11 & 16 \\
\hline
\end{tabular}

Three basic elements were identified before. According to Table-II, it indicates the numbers of researchers who study on each of the basic elements. Cavity, shading devices and inner and outer skin glaze façade are the main basic components for DSF as mentioned before. According to table 2.0, majority of the researchers study on the cavity space while 16 researchers study on the shading device and 11 researchers study on inner and outer skin glaze façade. Base on this study, it indicates that cavity space is the main study elements among researchers followed by shading device and inner and outer skin glaze façade. This study also revealed that cavity space is the main basic elements that integrated together with shading device and inner and outer skin glaze façade. All of these elements contribute and work together to produce the DSF efficiency design.

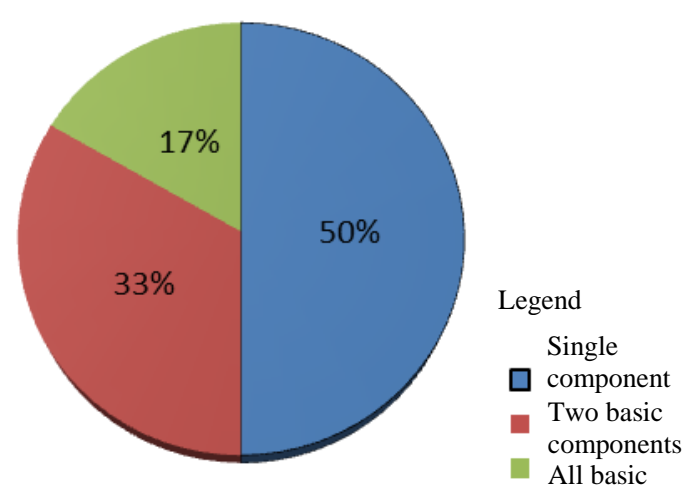

Fig. 1.Numbers of DSF's basic elements study by researchers

According to Figure 1, 50\% of the researchers are focus on single basic components of DSF. 33\% of researchers study on two basic components and $17 \%$ are study on all of the DSF's basic components. This data indicates that, most of researchers have their own specialty to study certain basic components. They found the issue that inspired them to focus and enhance the quality of the basic component. Some of the researchers focus on two basic components such as cavity with shading device and shading device with inner and outer skin glaze façade. Unfortunately, based on this study shows that none of the researchers study on the relation between cavity space with inner and outer skin glaze façade as indicates in Table-III.

Table-II: Numbers of study on the DSF basic components

\begin{tabular}{|l|c|c|c|}
\hline & Cavity & $\begin{array}{c}\text { Inner and outer } \\
\text { skin glaze } \\
\text { facade }\end{array}$ & $\begin{array}{c}\text { Shading } \\
\text { device }\end{array}$ \\
\hline Cavity & \multicolumn{1}{|c|}{$\mathrm{X}$} & 0 \\
\hline $\begin{array}{l}\text { Inner and } \\
\text { outer skin } \\
\text { glaze facade }\end{array}$ & $\mathrm{X}$ & \multicolumn{1}{|c|}{} \\
\hline $\begin{array}{l}\text { Shading } \\
\text { device }\end{array}$ & $\bullet$ & $\bullet$ & \\
\hline
\end{tabular}

$17 \%$ (3 researchers) study all of the DSF basic components which are Loncour et al.and Poirazis and Ding et al.

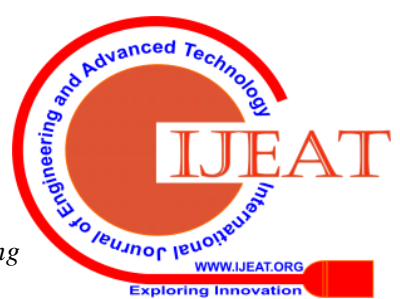


They are among the pioneers since they study on DSF in early 2000 and definitely they have more information on all of the basic components. Besides, some of their study were been cited by most of the researchers especially Poirazis which indicates that his research and information is the most preferred references for DSF.

\section{CONCLUSSION}

As a conclusion, most of the researchers define DSF base on three main basic components which are cavity, shading device and inner and outer skin glaze façade. Each of the components is integrated to produce an efficient DSF design that contributes to produce a quality of indoor spaces and better outdoor environment. Besides, basic components of DSF can be enhanced with other additional components that depend on the issue and objective to adopt DSF design. Researchers are mostly study on this basic component that related to the natural environmental elements such as natural ventilation, heat, noise and day lighting. Definitely, cavity needs to be function with shading device and inner and outer skin glaze façade.

Most of the research is focus on single basic component that base on the issue and objective to adopt DSF to a building's façade. Less research focuses on all of the three basic components as indicator to encourage other researchers to explore more on the other basic components for DSF. Unfortunately, none of the researchers study the relation between cavity and inner and outer skin glaze façade to produce a better DSF design.

Overall, passive DSF design is another sustainable part of façade's building design that should be explores more among researchers as well as people who are involved in the construction industries. DSF possessed a high potential to create a sustainable building's façade design that enhance occupant's activities, indoor and outdoor building's environment.

\section{ACKNOWLEDGMENT}

The authors thank the Universiti Kebangsaan Malaysia (DIP-2016-006) and Ministry of Education (MyPhd and FRGS/1/2017/TK06/UKM/02/2) for proving their financial support which made this study possible.

\section{REFERENCES}

1. Abdul Aziz, A. \& Mohd Adnan, Y. 2008. Incorporation of innovative passive architectural features in office building design towards achieving operational cost saving-the move to enhance sustainable development. 14th Pacific RIM Real Estate Society (PRRES) Asia Pacific Seminar : 1-11.W.-K. Chen, Linear Networks and Systems (Book style). Belmont, CA: Wadsworth, 1993, pp. 123-135.

2. Aksamija, A. 2013. Sustainable Facades: Design Methods for High-performance Building Envelopes. New Jersey: John Wiley \& Sons, Hoboken.

3. Andelkovic, A.S., Urosevic, B.G. \& Kljajic, M. 2015. Experimental research of the thermal characteristics of a multi-storey naturally ventilated double skin facade. Energy and Buildings 86(2015) : 766-781.

4. Baharvand, M., Ahmad, M.H., Abdul Majid, R. \& Safikhani, T. 2012. Thermal comfort and double skin facade in hot and humid climate. Malaysia: Institue Sultan Iskandar, Universiti Teknologi Malaysia.

5. Barbosa, S. \& Ip, K. 2014. Perspective for double skin facades for naturally ventilated buildings: A review. Renewable and Sustainbale Energy Reviews 40(2014) : 1019-1029.

6. Barbosa, S, Ip, K. \& Southal, R. 2015. Thermal comfort in naturally ventilated buildings with double skin facade under tropical climate conditions: The influence of key design parameters. Energy and Buildings 109(2015) : 397-406.
Cavity is the most common basic components to DSF.

7. Batungbakal, A., Konis, K., Gerber, D. \& Valmont, E. 2013. The acoustic performance of double-skin glass facades : A design support tool for architects. Advancing Towards Net Zero, Pomona, California, USA : 226-230.

8. Belgium Building Research Institute (BRRI). 2002. Source book for a better understanding of conceptual and operational apects of active facade version 1. Belgium : Department of Building Physics, Indoor Climate and Building Services.

9. Boake, T.M. 2003. The tectonics of the double skin: Understanding double facade system. Slaid. United State : University of Waterloo.

10.Chan, A. L. S. \& Chow, T. T. 2012. Calculation of overall thermal transfer value (OTTV) for commercial buildings constructed with naturally ventilated double skin facade in subtropical Hong Kong. Energy and Buildings, Elsevier 69(2014) : 14-21.

11.Chan, A.L.S., Chow, T.T., Fong, K.F. \& Lin, Z. Investigation on energy performance of double skin facade in Hong Kong. Energy and Buildings 41(2009) : 1135-1142.

12.Ding, W., Hasemi, Y. \& Yamada, T. 2005 Natural ventilation perfromance of a double-skin facade with solar chimney. Energy and Buildings 37(2005) : 411-418.

13.Eren, O \& Orturan, B. 2013. Sustainable buildings with theri sustainable facades. IACSIT International Journal of Engineering and Technology 5(6) : 725-730.

14.Gavan, D., Woloszyn, M., Kuznik, F. \& Roux, J.J. 2010. Experimental study of a mechanically ventilated double-skin facade with venetian sun-shading device: A full-scale investigation in controlled environment. Solar Energy Elsevier 84(2):183-195.

15.Gelesz, A. \& Reith, A. 2015. Climate-based performance evaluation of double skin facades by building energy modelling in Central Europe. Science Direct 78(2015) : 555-560.

16.Ghaffarianhoseini, A., Ghaffarianhoseini, A., Berardi, U., Tookey, J. Li, D.H.W. \& Kariminia, S. 2016. Exploring the advantages and challenges of double-skin facades (DSFs). Renewable and Sustainable Energy Reviews 60(2016) : 1052-1065.

17.Ghonimi, I. 2017. Assessing daylight performance of single vs. double skin facade in educational buildings : A comparative analysis of two case studies. Journal of Sustainable Development 10(3) : 133-142.

18.Goia, F., Haase, M. \& Perino, M. 2013. Optimizing the configuration of a facade module for office buildings by means of integrated thermal and lighting simulations in a total energy perspective. Apllied Eenergy 108(2013) : 515-527.

19.Gratia, E. \& Herde, A.D. 2003. Optimal operation of a south double-skin facade. Energy and Buildings 36(20074 : 41-60.

20.Gratia, E. \& Herde, A.D. 2007. Are energy consumptions decreased with the addition of a double-skin?. Energy and Buildings 39(2007) : 605-619.

21.Hendriksen, O.J., Sorensen, H., Svensson, A. \& Aaqvist, P. 2000. Double skin facades - Fashion or a step towards sustianble buildings. International Soalr Energy.

22.Ignjatovic, M. G., Blagojevic, B. D., Stojanovic, B. V. \& Stojiljkovic, M. M. 2012. Influence of glazing types and ventilation principles in double skin facades on delivered heating and cooling energy during heating season in an office building. Thermal Science 16(2012):461-469.

23.Jiru, T.E. \& Haghighat, F. 2008. Modeling ventilated double skin facade-A zonal approach. Energy and Buildings 40(2008) : 1567-1576.

24.Joe, J., Choi, W., Kwak, Y. \& Huh, J. H. 2014. Optimal design of a multi-story double skin facade. Energy and Buildings, Elsevier 76(2014) : 143-150.

25.Kim, D. Cox, S. J., Cho, H. \& Yoon, J. 2018. Comparative investigation on building energy performance of double skin facade (DSF) with interior or exterior slat blinds. Journal of Building Engineering 20(2018):411-423.

26. Kuznik, f., Catalina, T., Gauzere, L., Woloszyn, M. \& Roux, J. J. 2011. Numerical modelling of combined heat transfers in a double skin facade - Full-scale laboratory experiment validation. Applied Thermal Engineering 31(20111):3043-3054.

27. Kurniansyah, R., Nugroho, A.M. \& Martiningrum, I. 2016. Double skin facade strategy for apartment in Surabaya. Jurnal Mahasiawa Jurusan Arsitektur 4(4).

28. Larsen, S.F., Rengifo, L. \& Filippin, C. 2015. Double skin glazed facades in sunny Mediterranean climates. Energy and Buildings 102(2015) : 18-31.

29. Lee, J, Alshayeb, M \& Chang, J.D. 2015. A study of shading device configuration on the natural ventilation efficiency and energy performance of a double skin facade. Procedia Engineering 118(2015) 310-317.

Published By: 
30. Lee, J \& Chang, J. D. 2015. Influence on vertical shading device orientation and thicknesson the natural ventilation and acoustical performance of a double skin facade. Procedia Engineering 118(2015):304-309.

31. Loncour, X., Deneyer, A., Blasco, M., Flamant, G. \& Wouters, P. 2004. Ventilated Double Facades : Classification \& illustration of facade concepts. Belgium : Belgian Building Research Institute.

32. Lou, W., Huang, M., Zhang, M., \& Lin, N. 2012. Experimental and zonal modeling for wind pressures on double-skin facades of atall building. Energy and Buildings 54(2012) : 179-191.

33. Luo, Y., Zhang, L., Wnag, X., Liu, Z. \& Wu, L. Z. 2017. Modeling of solar transmission through multilayer glazing facade using shading blinds with arbitry geometrical and surface optical properties. Energy 128(2017):163-182

34. Mulyadi, R., Yoon, G. \& Okumiya, M. 2012. Study on the energy performance of double-skin facade in Indonesia. Transactions of the Society of Heating, Air-Conditioning and Sanitary Engineers of Japan 183(2012) : 9-17.

35. Nasrollahi, N. \& Salehi, M. 2015. Performance enhancement of double skin facades in hot and dry climates using wind parameters. Renewable Energy 83(2015) : 1-12.

36. Nicol, F., Humpreys, M., \& Roaf, S. 2012. Adaptive Thermal Comfort: Principles and Practicse. London: Routledge.

37. Oesterle, E., Lieb, R.D., Lutz, G. Heusler, B. 2001. Double-skin facades: Integrated planning building physics, construction, aerophysics, air-conditioning, economic viability. Munich: Prestel.

38. Papadaki, N., Papantoniou, S. \& Kolokotsa, D. 2012. A parametric study of the energy performance of double-skin facades in climatic conditions of Crete, Greece. International Journal of Low-Carbon Technologies 2014(9):296-304.

39. Pappas, A. A. 2006. Energy modeling of a double skin facade a method using CFD \& energy plus. Master Thesis. University of Colorado.

40. Peng, J., Lu, L. \& Yang, H. 2013. An experimental study of the thermal performance of a novel photovoltaic double-skin facade in Hong Kong. Solar Energy 97(2013) : 293-304.

41. Poirazis, H. 2004. Double skin facades for office buildings : Literature review. Sweden : Lund University, Lund Institue of Technology.

42. Pollard, B. \& Beatty, M. 2008. Double skin facades: More is less? ISES-AP $-3^{\text {rd }}$ International Solar Energy Society Conference - Asia Pasific Region (IESI-AP-08), Sydney Convention \& Exhibition Centre : 1-25.

43. Pomponi, F., Piroozfar, P.A.E., Southall, R., Ashton, P. \& Farr, E. R.P. 2015. Life cycle energy and carbon assessment of double skin facades for office refurbishments. Energy and Buildings 109(2015) : 143-156.

44. Rahmani, B., Kandar, M.Z., Rahmani, P. 2012. How double skin facade's air-gap sizes effect on lowering solar heat gain in tropical climate?. World Applied Sciences Journal 18(6) : 774-778.

45. Rundel, C.A., Lightstone, M.F., Oosthuizen, P. Karava, P. \& Mouriki, E. 2011. Validation of computational fluid dynamics simulations for atria geometries. Building and Environment 46(2011) : 1343-1353.

46. Saelans, D. 2002. Energy performance assessment of single storey multiple-skin facades. Ph.D. Dissertation, K.U. Leuven, Belgium.

47. Safer, N., Woloszyn, M. \& Roux, J.J. 2005. Three dimensional simulation with a CFD tool of the airflow phenomena in single floor double-skin facade equipped with a venetian blind. Solar Energy 79(2005) : 193-203

48. Selkowitz, S.E. 2001. Integrating advanced facades into high performance buildings. 7th International Glass Processing Days, Tampere, Finland, June 18-21 : 1-9.

49. Silva, F. M., Gomez, M. G. \& Rodrigues, A. M. Measuring and estimating airflow in naturally ventilated double skin facades. Building and Environment 87(2015):292-301.

50. Viljoen, A., Dubiel, J., Wilson, M. \& Fontoynont, M. 1997. Investigations for improving the daylighting potential of double-skinned office building. Solar Energy 59(1997) : 179-194.

51. Wetsphal, F. S. \& Andreis, C. 2016. Influence of glazed facades on energy consumption for air conditioning of office buildings in Brazilian climates. Int. Journal of Engineering Researchand Application 6(11):54-60.

52. Wilkinson, S. J. \& Reed, R. G. 2006. Office building characteristics and the links with carbon emissions. Emerald Insight 24(3) : 240-251.

53. Winther, E.V., Liu, M. Heiselberg, P. \& Jensen, R. L. 2017. Experimental and numerical analysis of modelling of solar shading. Energy Procedia 132(2017):472-477.

54. Xue, F. \& Li, X. 2015. A fast assessment method for thermal performance of naturally ventilated double-skin facades during cooling season. Solar Energy 114(2015) : 303-313.

55. Yang, H. Zhou, Y. Jin, F. Y . \& Zhan, X. 2016. Thermal environment dynamic simulation of double skin facade with middle shading device in summer. Procedia Engineering 146(2016): 251-256.

\section{AUTHORS PROFILE}

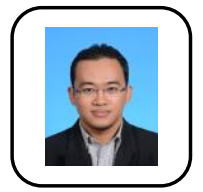

M. H. M. Zin is a PhD student at the Architecture Department of Faculty Engineering and Built Environment in Universiti Kebangsaan Malaysia (UKM). He graduated his Bachelor in Architecture in 2010 and Master Science in Architecture in 2013 from Universiti Kebangsaan Malaysia (UKM).

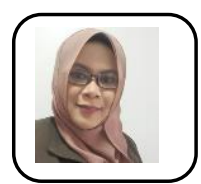

M. Jamil is an Associate Professor at the Architecture Department, Faculty Engineering and Built Environment in Universiti Kebangsaan Malaysia (UKM).

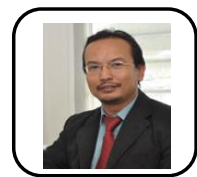

N. L. N. Ibrahim is an Associate Professor at the Architecture Department, Faculty Engineering and Built Environment in Universiti Kebangsaan Malaysia (UKM).

A. S. M. Tazilan is an Associate Professor at the Architecture Department, Faculty Engineering and Built Environment in Universiti Kebangsaan Malaysia (UKM) 